\title{
Trends in Children's Book Publishing, 1975-2000: Corporate Influences on Children's Reading
}

\author{
Kathy Latrobe, Professor \\ University of Oklahoma \\ School of Library and Information Studies \\ Norman, Oklahoma 73019
}

U.S.A

\begin{abstract}
Data gathered from selected supplements $(1975,1980,1985,1990,1995$, and 2000) to the Children's Catalog (H.W. Wilson), are analyzed to describe the corporate ownership of children's book imprints and assess trends and changes, including the decline of independent publishing entities in the early 1980s, the relative stability in the percentage of corporations that produce both large and small proportions of children's books, and the accelerated changes across the children's publishing industry during the past ten years. Conclusions address the influence of corporate ownership on the development, contents, accessibility, and marketing of books for children.
\end{abstract}

\section{Introduction}

The social effects of corporate mergers and acquisitions in the publishing industry have been prominent topics during the past 30 years across many disciplines, including that of library and information studies. In predicting the ultimate outcome of corporate consolidations on the publishing industry, Beth Luey wrote, "[S]ome analysts predict that perhaps a dozen huge firms will turn the democracy of publishing into an oligopoly that, within many nations, may approach monopoly" $(1992$, p.1). Within the publishing milieu, children's publishing holds a small and specialised niche in which similar predictions and concerns have been expressed, including, for example, publisher Stephen Roxburgh's claim that "children's book publishing is under assault" $(2000$, p.653). Others in the field have set forth specific concerns about the impact of the publishing industry's ownership on authors, readers, and library collections, including, for example,

- the "threat of too few information producers with access to a free market (Evans, 2000, p. 132)

- the challenge that the imports boom present to local (c.g., Taiwanese) children's literature industries (Bradbury \& Liu, 2003, p.246)

- a bottom-line emphasis of large corporations to discourage risk-taking and innovation (Burroughs, 1989, p 138)

- the potential that "individual books will get overlooked when lists are combined" (Burroughs, 1989, p.139)

- the loss of identity and autonomy for "established editorial lines" (Burroughs, 1989, p. 138) 
- a trend that writers from countries with smaller literary markets, for example, Canada (Aldana, 2001, p.676) and the Republic of Ireland (Parkinson, 2001, p.178), will look to countries (and corporations) that offer greater publishing opportunities

- ownership by large media conglomerates that market to children, not as readers, but as consumers of "spin-off merchandise" (Hade, 2002, p.509)

- weakened and tentative relationships between authors and editors (Latrobe and Schwartz-Porter, 1996, p.14)

- a tendency toward "cultural massification," when, for example, "our assumptions about what good literature is, or indeed what literature is, may be deeply challenged" (Long, 1992, p.93).

There are also perceptions that larger corporations offer advantages. Ginee Sco, an editorial director at HarperCollins Children's Books, has noted, "Big companies can pay more, can invest in careers, and . . a apply the resources of smart people in a lot of areas" (cited in Roback \& Britton, 2000, p.92). Seo also points out that larger companies have more clout with book store chains and more marketing capacity as well as an increased ability to implement tailored marketing. Mary Ann Sabia observed that smaller houses can "benefit from the negatives at huge houses, like lack of individual attention for authors" and that authors who have been displaced through mergers and acquisitions "are looking for a stable home" (cited in Roback \& Britton, 2000, p.93). Furthermore, Doug Whiteman, president and publisher of Penguin Books for Young Readers observed, "Despite the changing climate, or perhaps because of it, alternative retail markets are cropping up" (cited in Roback \& Britton 2000, p.93).

These points of view, both positive and negative, motivated the basic question of this research, a question humorously asked by Ben Bagdikian in 1987 ,

Is it possible, we're heading

Towards one great climactic wedding

When all but two remain unmerged,

The rest absorbed, acquired or purged (p. 12).

However, before that question with all its implications can be asked, what exactly has been happening? Are there trends that can be charted? More specifically for this study, what was the pattern and rate of corporate mergers and consolidations from 1975-2000 for the publishers of books likely to be found in the children's library collections in the United States? And, what do the trends and patterns of corporate ownership of the children's book publishing industry imply for librarianship?

\section{Methodology}

These questions were approached by identifying and analysing the corporate parents of the imprints represented in children's library collections in the United States from 1975 through to 2000. For the purposes of this study, the standard source for identifying the population of books that represented the profession's best judgement on what, in any given year, was worthy to be added to a well-developed children's collection was the H. W. Wilson's Children's Catalog, and more specifically its annual supplements which focused on books contemporary to the years studied rather than on the retrospective view of the bound 
editions. Furthermore, to frame trends across the last quarter of the twentieth century, especially in regard to patterns and rates of consolidations within the United States, the entire set of children's books were sampled from the Children's Catalog Supplement for the years $1975,1980,1985,1990,1995$, and 2000. Thus, data collection and analysis focused on the set of imprints producing children's books suitable to library collections and respectively current to the six supplements framing the five-year intervals from 1975 to 2000. Each corporate parent's representation of books in the Children's Catalog Supplement for each of the six years studied was calculated from that data. Corporate ownership of the various imprints and companies at the time of each sampled book's publication was verified in most cases from multiple volumes of two reference resources: the Dircctory of Corporate Affiliations (National Register) and The International Directory of Company Histories (St. James). In some cases, imprint ownership was sought or confirmed through two other sources: Publishers Weekly and corporate Web sites.

\section{Results}

\section{Summary Data}

Simply comparing the number of parent companies represented in each of the six supplements reveals an apparent shift in the ownership of children's book publishing. Figure 1 portrays the loss of parent corporations that occurred between 1980 and 1985 when ownership of imprints decreased from 58 entities to 38 , a $35.6 \%$ decline which remained in place across 1990, 1995, and 2000.

The 1980s shift in ownership indicated within this study of children's publishing was confirmed across book publishing in general by John Baker who observed that the "rate of merger and take-over lessened considerably in 1985 from what it had been in previous years" (1986, p. 27). The relatively high rate of merger and take-over in the early $1980 \mathrm{~s}$ is underscored by the fact that in the less active year of 1985, purchases in the industry included those of Dutton by New American Library, of Holt, Rinchart, and Winston by the Georg von Holtzbrinck, and of Ginn \& Company by Gulf \& Western.

However, despite the ownership change in the 1980s, the six supplements indicate one type of consistency across the twenty-five years: a relatively stable proportion of contributing corporations appear to follow a similar pattern in the level of their books' representation across the supplements to the Children's Catalog.

Table 1 sets forth, in 10\% intervals, summary data for the cumulative percentage of parent corporations (ranked in descending order by the number of titles each contributed to the year's supplement) according to the percentage of their contributions to the respective year's supplement. 


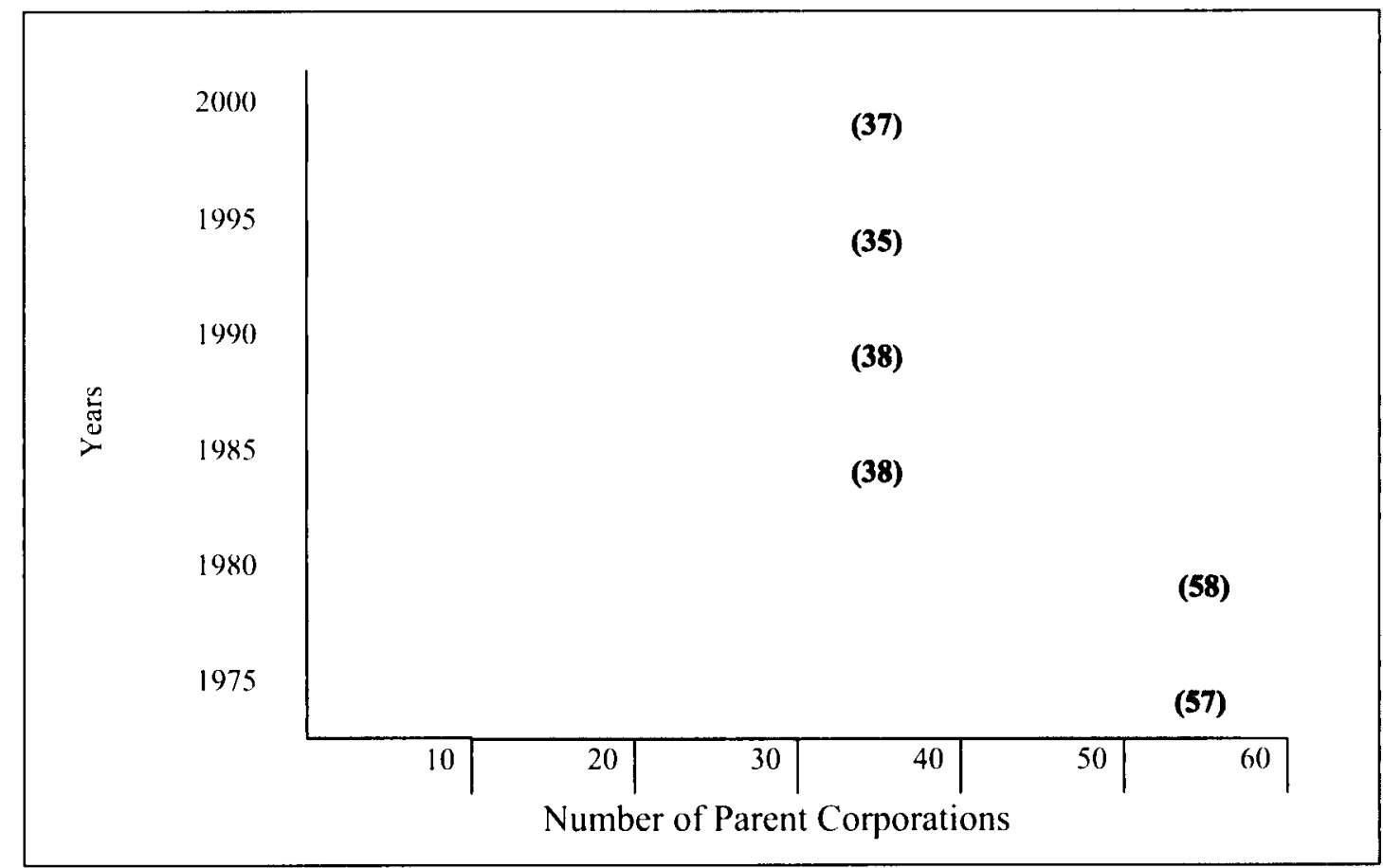

This pattern of corporate contributions over the twenty-five years is presented in Figure 2 which identifies ranges of corporate contributions to each annual supplement. For example, approximately $50 \%$ of the corporations accounted for $90 \%$ of the titles listed in each annual supplement. The darker shaded cell in each of the $10 \%$ intervals represents at least four of the six years considered; thus, together the darker cells indicate an underlying stability of corporate concentration across the six supplements. Notably, for recent years, ten to thirty percent of the most frequently represented corporations set the proportionally lowest number of contributions to the annual supplements in 1995 and the highest in 2000 , indicating a time of increased volatility in corporate concentration. Thus, the findings of the study reveal that

- there was a $35.6 \%$ decline (1975-2000) in the number of parent corporations represented in the supplements to the Children's Catalog

- for four of the six supplements studied, there were relatively stable ranges wherein, for example, $10 \%$ of the most frequently included corporations contributed between 40 and $45 \%$ of the books, for example, $20 \%$ of the corporations contributed between 60 and $65 \%$, and

- by the year 2000 , three global corporations produced over $50 \%$ of the books in the supplement to the Children's Catalog. 
Table I Percentage of Titles to Supplements of the Children's Catalog

\begin{tabular}{|c|c|c|c|c|c|c|c|c|c|c|}
\hline 2000 & 50.9 & 74.7 & 83.1 & 92.1 & 93.0 & 93.9 & 96.9 & 97.4 & 98.4 & 100 \\
\hline 1995 & 33.4 & 57.6 & 71.8 & 85.6 & 92.1 & 96.7 & 97.9 & 98.8 & 99.5 & 100 \\
\hline 1990 & 42.9 & 65.8 & 79.0 & 88.2 & 95.2 & 96.0 & 96.7 & 97.9 & 99.4 & 100 \\
\hline 1985 & 44.8 & 64.2 & 74.8 & 81.9 & 90.3 & 93.3 & 95.6 & 96.5 & 97.0 & 100 \\
\hline 1980 & 42.6 & 64.2 & 77.5 & 83.1 & 89.9 & 92.5 & 95.3 & 96.5 & 97.5 & 100 \\
\hline 1975 & 42.6 & 61.8 & 74.5 & 85.2 & 90.4 & 92.8 & 94.4 & 97.1 & 97.8 & 100 \\
\hline & 10 & 20 & 30 & 40 & 50 & 60 & 70 & 80 & 90 & 100 \\
\hline
\end{tabular}

Descending Cumulative Pereentage of Parent Corporations

Figure 2 Ranges* for Percentage Books in Supplements to the Children's Catalog

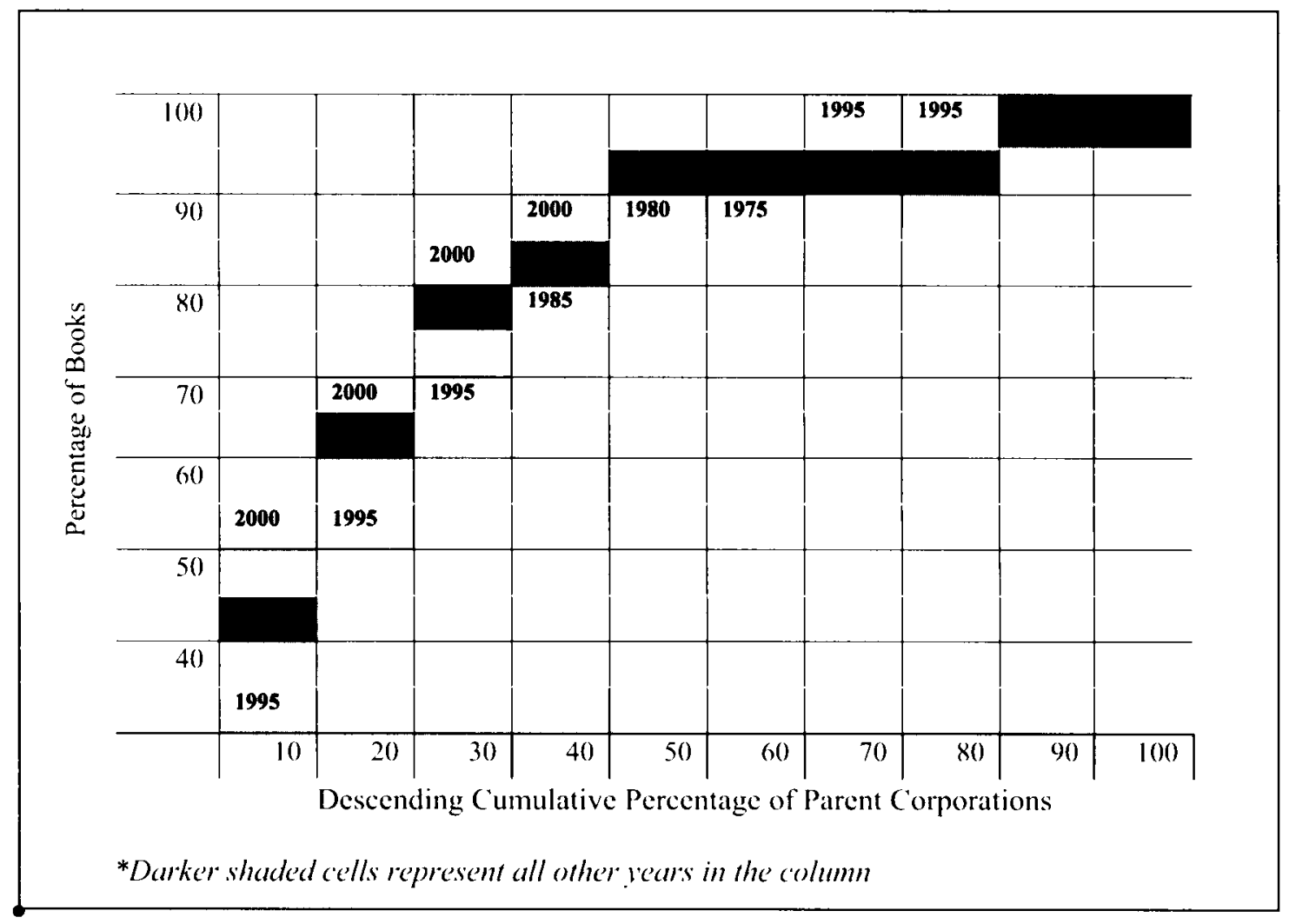

Structurally, by 2000 , the children's book publishing industry resembled a pyramid. with a few giant groups at the top. Furthermore, those few were global multimedia amalgamations. For example, in 1975, 1980, and 1985, Macmillan, with its own set of 
acquisitions, had been in the upper $10 \%$ of publishers represented in the Children's Catalog supplements; however, in 1988 it was purchased by Maxwell Communication Corporation.

In 1994 Simon \& Schuster (owned since 1989 by Paramount) purchased Macmillan, and also in 1994 Viacom merged with Paramount, bringing the histories of Simon \& Schuster and Macmillan into a media corporation with vast holdings that included CBS, Blockbuster, Castle Rock Entertainment, numerous TV stations, and notable book imprints. Among other global multimedia corporations with representation in the 2000 supplement were AOL Time Warner, Vivendi, Bertelsmann, and Disney.

Histories of corporations suggest that there are multiple reasons for takeovers and acquisitions. Smaller publishers often are confronted with acquisition when they experience cash-flow difficulties. If they are publicly owned, there can also be pressures from stockholders who see personal gains. In addition, small publishers seem to be especially challenged by conglomerates in market viability, including their ability to draw leading authors. In purchasing smaller publishers, giant corporations are often buying position in niche markets. When giant media corporations purchase large publishing houses like Harper \& Row, they can gain position across a continent, pursue economies of scale, and find synergy across their vertically integrated holdings.

\section{Illustrative case histories}

\section{A tale of two publishers}

The potential effect of corporate structure and ownership on a children's book publishing entity is illuminated through the comparison of disparate corporate histories. Two contrasting examples of corporate structure and ownership are Holiday House and News Corporation. Holiday House, founded and held as a private company since 1935, contributed from six to 24 books in each supplement to the Children's Catalog, averaging 13.5 per supplement. News Corporation, the parent company of HarperCollins, had 91 books represented in the 2000 supplement.

News Corporation Limited is the holding company for the vast array of businesses created or acquired since the 1950s by Rupert Murdoch, who became the largest publisher of English-language books and owner of television stations, broadcasting companies, film production companies, printing firms, and airlines. Murdoch was born in Melbourne in 1931, the son of a managing editor of an Australian newspaper group. By 1987, he had become an American citizen, and that year he gained prominence in the U. S. children's book publishing industry when he bought Harper \& Row, of which he immediately sold half to William Collins and Sons of Britain. Murdoch's purchase of Harper \& Row concentrated further previous amalgamations within that company. For example, Harper \& Row, previously had been partly owned by Cowles Media in the 1970s. Although struggling to break even during the 1970s, Harper \& Row purchased Lippincott in 1977 and Crowell in 1978. Two years after Murdoch had sold part of Harper \& Row to Collins, he purchased William Collins and Sons outright (1989), and Harper \& Row became HarperCollins. The acquisition of Collins occurred at a time of New Corporation's growing debt which by 1990 was $\$ 8.2$ billion. Murdoch restructured and sold over $\$ 800$ million in businesses. By 1991 Murdoch had avoided bankruptcy, and News Corporation's profits accelerated. Murdoch's next major venture into U.S. children's publishing came in 1999 when the Hearst Corporation agreed to 
sell William Morrow \& Company. News Corporation's purchase of Morrow included the imprints of Beech Tree, Greenwillow, Lothrop Lee \& Shepard, Mulberry, Tupelo, and Morrow Junior. Thus, sitting at the apex of decades of mergers, acquisitions, and takeovers within the children's book publishing industry, News Corporation contributed the most titles (91) to the 2000 supplement. The magnitude of News Corporation's impact is underscored by the fact that the Hearst Corporation, having held Morrow for almost twenty years, had been the largest contributor to the 1985 supplement. However, the number of News Corporation's books in 2000 did not equal the sum of Hearst Corporation's 63 books and New Corporation's 47 in 1995. The year 1995 was also when the most frequently represented company in the supplement was Pearson, the first major corporation headquartered outside the United States to hold that position. Following News Corporation's representation in the 2000 supplement was Scholastic ( 80 books) and then Pearson (63 books). Thus, by 2000 News Corporation was one of three global publishers likely to be producing more than half of the books added to children's library collections in the United States.

The history of Holiday House differs from that of News Corporation and even from that of many other privately held publishing companies, in part because it has had a continuous focus on being an independent publisher of books for children. Holiday House, during the 1940s did have an informal agreement with William R. Scott and Frederick Warne to share office space and at least one support position. However, the arrangement was discontinued because it did not cut costs; and afterwards, Holiday House remained completely independent. This company is also different from many other independent publishing houses because of an atmosphere which authors publicly describe as supportive. Many Holiday House authors consider John and Kate Briggs and the Holiday House staff to be their friends. Furthermore, the company itself has had a fairly flat structure, with marketers, editors, administrators, and owners working in a large open area in a single-floor office, reminiscent of the original partners working at three desks in the corner of a printing company. However, like all publishing businesses, Holiday House has coped with change, including: in the 1950s, a shift in sales of children's books from bookstores to schools and public libraries; in the 1960s the rapid growth in school library sales after the passage of the Elementary and Secondary Education Act directed significant federal funding into school library budgets, and in the 1980s a shift of sales back to retail stores and a backlist that could no longer offer the security it once held. Russell Freedman captured John Briggs' personal philosophy in The First Sixty-five Years,

Common corporate wisdom, in this country anyway, has been to diversify - the thinking being that it is dangerous to have all your eggs in one basket. . . . So, what can we do? Small independents tend to have more clearly defined financial limitations than the large companies and thas do not have as much choice when it comes to diversification. For most of us, reality seems to offer two options-we can either stay the way we are or sell out. As for Holiday House, we plan to go on in our independent way and continue to publish for our favorite audience and, we hope, a hetter world. (Freedman and Elleman. (2000), p.112).

In The Business of Books, André Schiffrin could have been writing about Holiday House when he stated, "In Europe and in America ... [publishers] have always prided themselves on their ability to balance the imperative of making money with that of issuing worthwhile books" (2000, p. 5). Upon selling the Holiday House in 1965, Vernon Ives commented on this kind of pride in the buyer whom he described as a young man, "who 
wants to continue the firm as it has been built up over the years: a small, independent quality publisher of children's books."

\section{Implications}

\section{Contents, accessibility, development, and the marketing of books}

The quality of books published for children is an underlying factor in this study, given that in recent years approximately only ten percent of the U.S. children's books published are selected for inclusion in supplements to the Children's Catalog. Therefore, those who manage children's collections may ask, "How does the quality of the books vary across the distributions of publishers?" One would expect more award-winning books to be in the sets of books published by the largest contributors to any given supplement.

To consider this secondary question, the 42 Newbery, Caldecott award and honour books for the six years represented in this study were identified, linked to their parent companies, and aligned by their respective years to the supplements, according to the size of the contribution of the various publishers. Thus, Figure 3 indicates that for the years considered $(1975,1980,1985,1990,1995$, and 2000) 19 books recognised by Newbery and Caldecott awards were published by the $10 \%$ of the corporations that, for their respective years, contributed the largest number of books to the supplement. Representing $42 \%$ of the award and honour books, those 19 books were in the range represented in the six annual supplements. Likewise, 27 award and honour books (64\%) were published by the $20 \%$ of the publishers most frequently represented in the respective supplements. However, the percentage of award and honour books exceeded publishers' contributions to the supplements at the $30 \%$ level and above. Thus, $60 \%$ of the publishers most often represented in the supplements published $100 \%$ of the award and honour books.

In no year did a publisher whose contribution to the supplement fell into the lower $40 \%$ earn recognition by the Newbery or Caldecott committee. Thus, data gathered does suggest a positive relationship between the size of a corporation's contribution to a supplement of the Children's Catalog and its ability to produce a children's book recognised for highest quality. Although determining the cause of the apparent relationship is beyond the scope of this study, among possible explanations are the corporations' capacities to invest in authors and illustrators, book production, and marketing and to acquire promising works and other publishing entities.

Although there was a concentration of publishing entities among the awards presented in the six selected years that framed the study, there was no identifiable trend in the variations across the years. However, the concentration was greatest in 2000, when the set of Caldecott and Newbery award and honour books was published by $30 \%$ of the largest contributors to the supplements. In that year, five corporations won eight recognitions. Six of those eight recognitions went to the three largest contributors to the 2000 supplement: two to News Corporation; one to Scholastic, and three to Pearson.

Literary quality is a principal consideration in selecting books for young people. However, there are also other important qualities, among which are innovation and diversity; two factors that can be viewed as demanding risk-taking in a corporate environment. Why take a chance on an unknown author? In fact, why not invest heavily in five to ten authors who are already stars? Why publish a book other than a fantasy when Harry Potter has been 
so successful? Why publish about a minority cultural or small national population when their market segments also have minority status? Why consider the child as a reader when the child as a consumer holds so much more marketing potential?

Figure 3: Concentration of Parent Publishing Companies Represented in Six Supplements to the Children's Catalog Compared to Those Recognised by the Newhery and Caldecott Committees for 1975, 1980, 1985, 1990, 1995, and 2000)

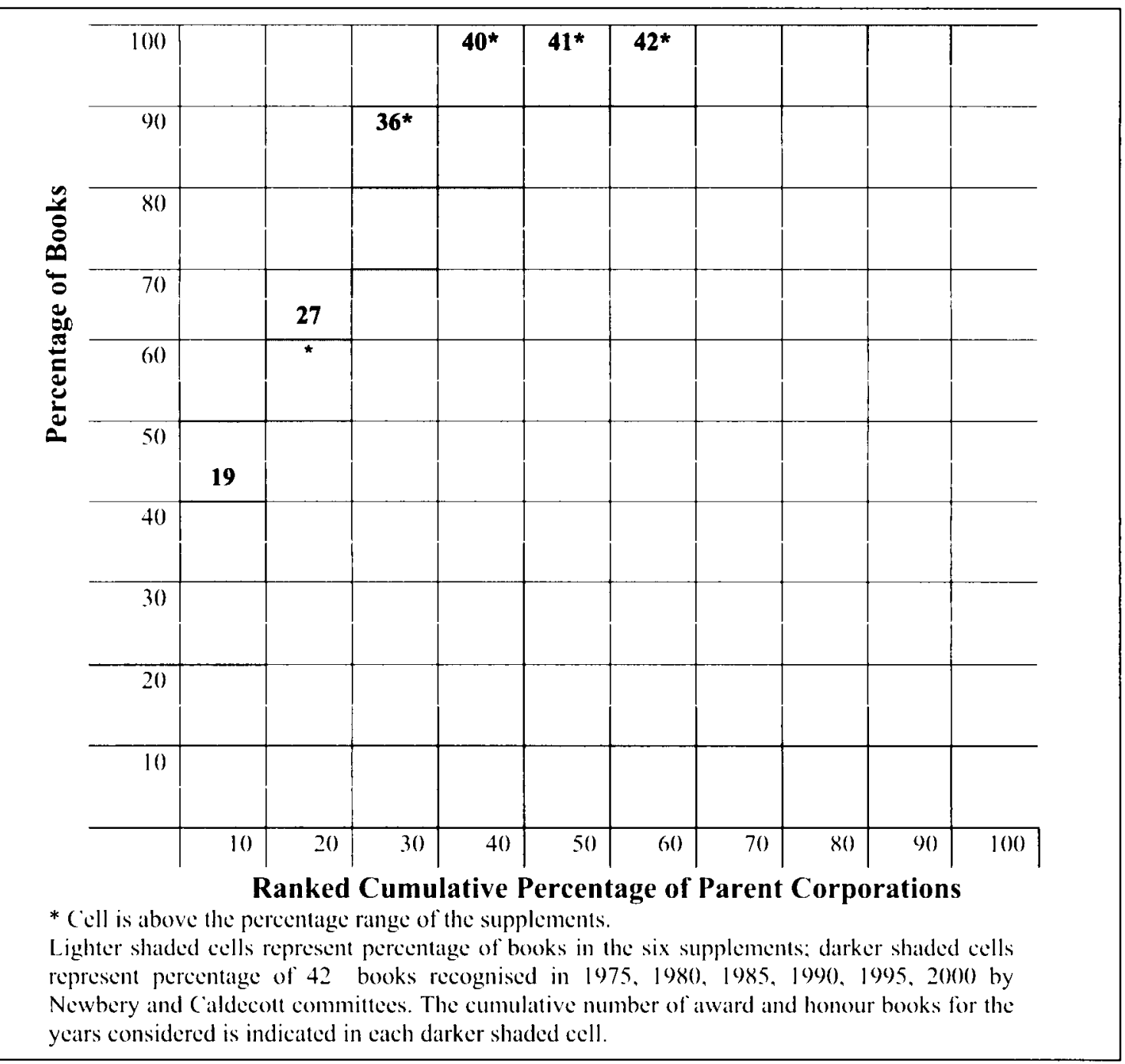

It has always been the case that such questions have existed in companies that either made a profit or were replaced by companies with the potential to make a profit. However, as a marketing director in the children's book publishing industry observed, today there are fewer companies, but more accountants. Describing the nature of companies whose focus was on profit margins, Jason Epstein in Book Business noted, "These men were not readers and could not empathise with people who were. .. . They would have been just as happy selling rose bushes or oranges by direct mail" (2001, p.39-40). Elaborating upon the rationale of applying market theory to the dissemination of culture, André Schiffrin wrote,

The market, it is argued, is a sort of ideal democracy. It is not up to the elite to impose their values on readers, publishers claim, it is up to the puthic to choose what it wants-and if what it wants is increasingly downmarket and 
limited in scope, so be it. The higher profits are proof that the market is working as it should (2000, p.103).

Schiffrin reported that over his career in publishing, expectations for profits increased from about $4 \%$ to $12-15 \%$, implying that the margin for risk taking likely has an inverse relationship to expected margin for profits.

It is the profit margin that places a greater value, as Daniel Hade wrote, on products about Curious George (e.g., T-shirts, lunch boxes, mouse pads, CD-ROMS, alarm clocks, ete) than the books about Curious George (2000, p.513). Many librarians note the impact of promotion from vertically integrated media companies that motivate young people to consider a book about a specific character in a movie, or even a toy or cartoon character, that they imagine surely is a book character, because they have seen it on TV. Some librarians have observed that the less reading children did, the more likely they would have an interest only in characters first met in the media.

\section{Implications for librarians}

As this study indicates, and as Barbara Elleman (1987, p.424) has noted, trends in children's book publishing can reverse from decade to decade. However, the principles of librarianship, especially those that guide the practices of collection development and library programming, do not change. Effective librarians still build good collections according to well-considered criteria, rely on professional selection tools, read widely, maintain balance and diversity within their collections, participate in book reviewing (as writers and readers), understand the nature of information production and packaging, and search widely for the book that meets a specific student's need or fills a cultural gap.

Principles of librarianship also support programming that involves young people in activities designed to extend book experiences. Creative dramatics, readers' theatre, interactions with author and illustrators, puppet plays, and art projects (c.g., murals, dioramas, and digital productions) directly involve students in reading and listening and responding to story with their own imaginations. For children with such literary experiences, the book character will have many dimensions more meaningful than the face on a lunchbox or clock. Further, good library programming extends to parents who appreciate understanding how reading and the joy of story are linked, developed, build relationships, and lead young people away from the passive participation demanded by many media productions. Good librarianship supports learning communities through the pleasure of books and story. Further, the mission of libraries remains stable despite political debates, corporate trends, and technological innovations.

\section{References}

Aldana, P. (2001). The intluence of money on children's book publishing. The horn book magazine, 77, 675681.

Bagdikian, B. (1987). The media brokers: concentration and ownership of the press. Multinational monitor, $8,7-12$.

Baker, J. (1986). The year in publishing. Publishers Weekly, 227, 26-29.

Bradbury, S. \& Feng-Hsin Liu, F. (2003). Everywhere a children's book: the view from Taiwan. The horn hook magazine, 79, 239-248.

Burroughs, R. (1989). Fitting into the conglomerate picture. Publishers week/y, 236, 138-140.

Children's catalog: 1975 supplement to the twelfth edition. (1975). New York: The H. W. Wilson Company. 
Children s'satalog: 1980 supplement to the thirteenth edition. (1980). New York: The H. W. Wilson Company.

Children's cataleg: 1985 supplement to the fourteenth edition. (1985). New York: The H. W. Wilson Company.

Children sc catulog: 1990 supplement to the fifteenth edition. (1990). New York: The H. W. Wilson Company.

Children's catalog: 1995 supplement to the sixteenth edition. (1995). New York: The H. W. Wilson Company.

Children's catalog: 2000) supplement to the seventeenth e'dition. (2000). New York: The H. W. Wilson Company.

Directory of corporate affiliations. (1975). Skokic, IL: National Register Publishing Co,

Directory of comporate affiliations. (1980). Skokic. IL: National Register Publishing Co.

Directory of corporate affiliations. (1985). Wilmette, IL: National Register Publishing Co

Directory of corporate affilitaions. (1990). Wilmette. IL: National Register Publishing Co.

Directory of corporate affiliations. (1995). New Providence, NJ: National Register Publishing Co.

Directory of forporate affiliations. (2000). New Providence, NJ: National Register Publishing Co.Elleman, B. (1987). Current trends in literature for children. Lihrug trends, 35, 413-26.

Elleman, B. (1987). Current trends in literature for children. Library trends, 35, 413-26.

Epstein. J. (2001). Book Business. New York: Norton.

Evans, (i. E. (2000). Dereloping lihrary and information center collections, $4^{\text {th }}$ ed. Englewood. CO) Libraries Unlimited.

Freedman, R. \& Elleman, B. (2000). Holiday House: The First Sixty-Five Years. New York: Holiday House. Hade, D. (2002). Storytelling: are publishers changing the way children read"? Honn hook magrazine, 78, 513.

The international directory of compamy histories. (1988-). (hicago: St. James, 1988-.

Latrobe, K. \& Schwarty-Porter, C. 1996. The bodies corporate: the new face of ehildren's publishing. Emergency librarian. 24, 14-19.

Long, F. (1992). The cultural meaning of concentration in publishing. In The structure of international publishing in the 1990s, ed. Fred Kobrak and Beth Luey, 93-117. New Brunswick: Transaction Publishers.

Luey, B. (1992). Introduction: the impact of consolidation and internationalization. In The structure of international publishing in the 1990), ed. Fred Kobrak and Beth Lucy, 1-22. New Brunswick: Transaction Publishers.

Parkinson, S. (2001). A view from the other island: children's books in Ireland. The horn hook magrezine, 77. 173-178.

Roback, D. E. (2000). A changing landscape. Puhlishers weekly, 247, 92-4.

Roxburgh, S. $(2000)$. Trilobites, palm pilots, and vampires: publishing children's books in the twenty-first century. The horn book magazine, 76, 653-660.

Schiffrin. A. (2000.) The Business of Books. New York: Verso.

\section{Author Note}

Since 1986 Kathy Latrobe has taught at the University of Oklahoma School of Library and Information Studies, focusing on materials and services for young people. Her special interests include the selection and evaluation of materials for children and young adults and the planning and evaluation of school library media programmes. 